\title{
Book Review: On the Fringes of Literature and Digital Media Culture: Perspectives from Eastern and Western Europe
}

The newly edited book On the Fringes of Literature and Digital Media Culture: Perspectives from Eastern and Western Europe by Irene Barbara Kalla, Patrycja Poniatowska and Dorota Michutka presents eye-opening research and literary experiments that are largely foreign to literary studies in Southeast Asia. The entries are divided into three broad categories: the debate over mainstream versus marginal literature, the gamification of narratives, and the portrayal of literary features in other digital mediums.

In the first chapter of Part 1: From the Centre to the Fringes and Back Again, Mariusz Pisarski introduces the concept of hypertextuality in electronic literature by studying the (e)merging works of Michael Joyce and Zuzana Husárová. He traces how Joyce's application of augmented reality combined with Husárová's poetic installations break the barriers of traditional literature by allowing readers the freedom and authority to determine the narrative direction of digital texts. This is achieved through the individual reader's personalized interaction and ordering of word choices available onscreen. While the experiment creates a plethora of narrative possibilities, Pisarski weighs the pros and cons of the method, citing the uncertainty of its future potentials. Yet, it is perhaps the mystery of the unknown evoked by the experience that draws the readers, much like how the turning pages of a traditional text enthrals them. Despite concerns, Pisarski is nevertheless assured that literature - in all its digital forms and beyond - remains very much alive.

Barbara Kaszowska-Wandor's explication on how the element of horror invokes fear which guides the digital reading experience makes up the second chapter of the book. This engaging piece utilizes the concept of deinosis, redefined by Keulen as a fixation upon horror and gruesome images, to highlight its presence in postmodern digital literature. By referring to various theories past and present, Kaszowska-Wandor believes that interaction through haptic reading engages the author and audience/reader in exploring and understanding their sense of self. This preoccupation with the Gothic continues to dominate the proceeding chapter discussing the legacy of the iconic literary figure, Edgar Allan Poe. Agata Zarzycka meticulously chronicles how Poe has achieved the status of a cult symbol in contemporary popular culture as the public recreates and adapts references to Poe and his works in their creative pieces. These range from popular motifs, music and media culture as well as internet memes. With each adaptation, Zarzycka recognizes how the newly crafted meanings gradually deviate from the thematic focus of Poe's original compositions. Similarly, the acceptance of these cultural appropriations has transitioned from author-centred discussions to audience-centred reception. Nevertheless, her study shows how literary canons of the past provide the foundation as literature transitions from conventional to digital with the line separating the two becoming increasingly blurred.

Following that, Emilia shares a fascinating comparison on the development of children's literature from paper books to electronic forms in accordance to the changing taste of the younger generations within a Ukrainian setting. While her effort is worthwhile, the language inconsistencies present within the article leads to a challenging read. Regardless, the strength of her research lies in its potential for replication in other parts of the world. Ultimately, it is a relief to know that, the popularity of electronic devices notwithstanding, children's literature in paper books are likely here to stay.

Arguably one of the most thought-provoking chapters in the book is Aleksandra Matecka and Piotr Marecki's experiment with rewriting the French text King Ubu into Polish using Google Translate. The authors present an indepth argument that prompts one to question the degree of originality involving creatively translated works, as opposed to translated creative works. Although the subject undertaken fits best within Polish culture, the study instigates similar pursuits with other forms of literary works. One point lacking, however, is an inquiry into the reception of the end product through its sales revenue which will unequivocally cement the strength of the enterprise.

The first section of the book closes with Dirk de Geest's novel study on creative writing handbooks which shape the assumption on the art of creative writing. In his analyses of these resources, the author identifies the variety of dictions and methodogies used, yet notes that almost all of the materials share a similarity in promising success to buyers who devote strict adherence to the writing processes suggested. In accordance to the theme and focus of the book in review, Geest also mentions how writing handbooks have begun to include electronic references but lacks rigorous discussion of electronic media for literary publications. This stems from the age-old belief that the success of a writer is measured via the publication of a printed book. It thus appears that despite the widespread digitalization of the publishing industry, the prominence of print media still triumphs.

Part 2: Where Narratives (Do Not) Fear to Tread opens with Aleksandra Mochocka's detailed expository on the The Witcher Adventure (Board) Game as part of the marketing strategy for the Witcher 3 series. The author does a thorough comparison between the board game and the original story as well as the video game version of the narrative. The chapter 
presents an enlightening discussion on the pros and cons of adapting the story into other forms including digital media, highlighting the elements that are retained post-adaptation and elements that are potentially lost during the process. Mochocka persuasively concludes that unlike the singular flow of the original story, which is solely dictated by the writer, the game requires interaction from its players to form new plot variations.

Dawn Stobbart's chapter on... the notion of narratology applied to the digital game Fallout 3, however, proves to be another challenging read within the book. An ambitious attempt, the author introduces a myriad of concepts and sub-concepts to explain the presence of environmental storytelling within the game. Unfortunately, these references signal a lack of focus which prevents the chapter from delivering a grounded thesis.

Mirocha and Fruzińska provide the compelling final two chapters of the section. The former dealt with transmedia storytelling, particularly through Netwars - out of control. Mirocha emphasises the potential monetary gains of such a genre, where an enterprising team will aim towards expansion of stories through films and video games, which then could lead to merchandising. Fruzińska, on the other hand, discusses the deeper questions that arises through the narratives provided in Call of Juarez: Gunslinger, specifically the validity of memory in telling stories. Fruzińska shows that while the narrative in Call of Juarez: Gunslinger is unreliable it does not distract from a player's enjoyment of the game. Both these chapters provide insights into the potential of narratives, and study of narratives, beyond the traditional printed texts.

Part 3: The Literary, the Digital and Their Social (Dis) Contents produces a mixed result for this book. Webb, Ślósarz, and Joyce's respective explorations of film, product-placements, and Vine videos and their literary qualities are fascinating topics, but lack focus. Webb made an interesting comparison between the original novel and film adaptations of Alice in Wonderland and The Classic Adventures of Paddington using concepts of the migrant. However, it would have been improved with more discussion on the monetary aspects of Hollywood films and its effect on the production of these adaptations. Ślósarz discussed the intentional advertising of products in novels, with strong examples from Anna Funder's Everything Precious and William Boyd's The Vanishing Game. But often other novels that use products to infer setting and mood are also included, which derails Ślósarz's arguments. On the Fringes of Literature and Digital Media Culture ends with Joyce's chapter on reading Szymborska's "Children of Our Age” alongside King Bach's 2014 Vine video "Racist Glasses" through Rousseau's idea on the "lie of literature". While a fascinating premise, the chapter would have benefited from less personal anecdotes (including a troubling admission of Joyce's own Racist Glasses) and less references to Joyce's own hypertextual works.

Jakubowiak, Žakevičienè, and Kasperek, on the other hand, provide illuminating analyses of the future of the literary industry in terms of copyright laws, the definition of literariness, and literary reviews respectively. Jakubowiak analyses entries in the Future of Copyright anthology from amateur writers and independent publishers. He comes across an interesting finding: that through fiction, the writers show a knowledge and worry over the future of copyright, illustrating the disastrous results of a world stuck in archaic laws, yet do not present their readers with solutions to these problems. Žakevičienè's chapter, which provides a look into the evolving relationship between print and digital media, begs the question - what is literature in today's digital world? Žakevičienè provides a partial answer, showing the potential of authors such as Leknickas being considered as a "certain story" or "narrative content" himself. But upon delving into Leknickas' actual 'literary' productions, Žakevičiene is unsatisfied. This is strange considering the quote he provides, that: "electronic literature [...] challenges us to re-think our assumptions of what literature can do and be" (Hayles 39). Perhaps Žakevičienè may want to give greater consideration and re-think assumptions of literature in regards to Leknickas" "simply" furnished texts of illustrations, photos, and fancy fonts. Finally, Kasperek argues convincingly that even though amateur bloggers write generally positive reviews, they provide a niche of reading and writing about less-reviewed books. She opens up the possibility of new areas of research on amateur blog reviews and their role in the production and reception of new literary works.

Florence Toh Haw Ching, Ikhlas Abdul Hadi

Faculty of Modern Languages and Communication, Universiti Putra Malaysia

Corresponding author: Florence Toh Haw Ching, E-mail: florence@upm.edu.my 